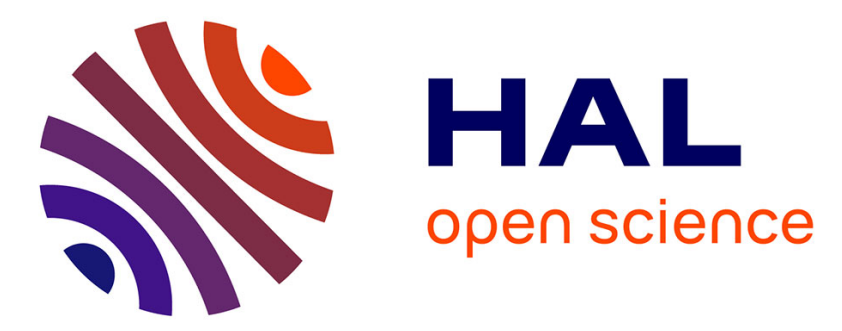

\title{
Assessing surface solar irradiance in Northern Africa desert climate and its long-term variations from Meteosat images
}

Magdy Abdel Wahab, Mossad El-Metwally, Reda Hassan, Mireille Lefèvre, Armel Oumbe, Lucien Wald

\section{To cite this version:}

Magdy Abdel Wahab, Mossad El-Metwally, Reda Hassan, Mireille Lefèvre, Armel Oumbe, et al.. Assessing surface solar irradiance in Northern Africa desert climate and its long-term variations from Meteosat images. International Journal of Remote Sensing, 2009, 31 (01), pp.261-280. 10.1080/01431160902882645 . hal-00356122v2

HAL Id: hal-00356122

https://hal.science/hal-00356122v2

Submitted on 2 Jan 2010

HAL is a multi-disciplinary open access archive for the deposit and dissemination of scientific research documents, whether they are published or not. The documents may come from teaching and research institutions in France or abroad, or from public or private research centers.
L'archive ouverte pluridisciplinaire HAL, est destinée au dépôt et à la diffusion de documents scientifiques de niveau recherche, publiés ou non, émanant des établissements d'enseignement et de recherche français ou étrangers, des laboratoires publics ou privés. 
Abdel Wahab M., El-Metwally M., Hassan R., Lefèvre M., Oumbe A., Wald L., 2008. Assessing surface solar irradiance in Northern Africa desert climate and its long-term variations from Meteosat images. International Journal of Remote Sensing, 31(01), 261 - 280, 2009. doi: 10.1080/01431160902882645.

\title{
Assessing surface solar irradiance in Northern Africa desert climate and its long-term variations from Meteosat images
}

\author{
MAGDY ABDEL WAHABף, MOSSAD EL-METWALLY*§, REDA HASSAN: \\ MIREILLE LEFÈVRE $\uparrow$, ARMEL OUMBE $\uparrow$ and LUCIEN WALD† $\dagger$ \\ ๆ Department of Astronomy and Meteorology, Faculty of Science, Cairo University, Cairo, \\ Egypt \\ $\S$ Department of Physics, Faculty of Science at Port Said, Suez Canal University, Port Said, \\ Egypt. \\ † Egyptian Meteorological Authority, Kubry El-Qubba, Cairo, Egypt. \\ $\dagger$ Mines ParisTech, Center for Energy and Processes, BP 207, 06904 Sophia Antipolis cedex, \\ France
}

Short title: Assessing solar irradiance in Northern Africa from Meteosat images

\begin{abstract}
Two databases of solar surface irradiance (SSI) derived from satellites are compared to ground measurements for Algeria, Egypt, Libya and Tunisia. It is found that it is possible to accurately derive the SSI from geostationary meteorological satellites, even with a coarse spatial resolution. The two databases HelioClim-1 and SSE exhibit similar and good performances. The bias is lower for SSE than for HelioClim-1, as a whole; inversely, HelioClim-1exhibits a smaller scattering of data compared to ground measurements (smaller standard-deviation) than the SSE, allowing better performances when mapping the long-term variations in the SSI. These long-term variations from 1985 to 2005 show that these four nations experience dimming as a whole. Detailed analyses of the range of dimming at sites with long-term records and of its spatial distribution have been performed. It has been found that the analysis of SSI from HelioClim-1 supports the findings for the individual sites. Several phenomena may explain the dimming. One is the transportation of sand dust northwards from the Sahel; another
\end{abstract}

Corresponding author, Mossad El-Metwally, Email: melmetwally@yahoo.com 
one is the increase in urbanization and a third one is the increase in cloud cover and aerosol loading.

\section{Introduction}

This paper deals with the irradiance observed at ground level on horizontal surfaces, also called surface solar irradiance (SSI). The SSI intervenes in many aspects in human, fauna and flora life in the desert climate in Northern Africa. Of particular interest nowadays to the four nations under concern in this paper: Algeria, Egypt, Libya, Tunisia, is the prospect of energy production from sun. These four nations comprise approximately 130 millions inhabitants altogether and solar energy is a key element for energy supply in the future. There are several techniques to produce heat and electricity from solar radiation. The SSI is the sum of the direct radiation, i.e., received from the direction of the sun, and of the diffuse radiation that originates from the other parts of the sky vault. Some systems are efficient only if they receive a large amount of direct radiation; others perform well also when the diffuse part represents a fair amount of the SSI. Efficient algorithms exist for the assessment of the direct and diffuse parts when the SSI is known (ESRA, 2000).

Accurate knowledge of the SSI permits to design and size systems, to predict yields and outputs of these systems and to monitor them by, e.g., comparing predicted/modelled outputs to actual ones (Drews et al., 2007; Imageen, 2004; Labed and Lorenzo, 2004; Langniss and Ince, 2004; Smyth et al., 2006). In many cases, monthly values are sufficient for a first insight of the SSI. Even for such broad measurements, the problem of availability of SSI data for any location is critical everywhere in the world because there is only a few number of stations measuring the SSI, except in Europe and Northern America (Cros et al., 2004b; SWERA, 2006). Referring to the World Meteorological Organisation documentation, Diabaté et al. (2004) mention that if Egypt is well covered with 9 measuring sites, they found only 1 in Algeria and Tunisia and none in Libya. Accordingly, there is a lack of knowledge on the spatial distribution of the monthly means of the SSI in these nations.

A number of models have been developed to palliate the lack of measurements of the SSI in this area (Abdel Wahab, 1987; El-Metwally, 2004, 2005; Ibrahim, 1985). They range from 
radiative transfer equations to the very simple regression models. The nature of radiation models in terms of simplicity depends mainly on the availability of input data and level of accuracy (Abdel Wahab, 1985). Solar resource assessment from geostationary satellites constitutes a powerful means to assess the SSI (Cano et al., 1986; Diabaté et al., 1988, 1989; Hammer et al., 2003; Perez et al., 1997, 2001; Pinker and Laszlo, 1992; Rigollier et al., 2004). The first purpose of this paper is to benchmark two databases derived from satellite data against available ground measurements of monthly means of SSI. These databases are the HelioClim-1 database, hereafter abbreviated to HC1, and the NASA-SSE (Surface meteorology and Solar Energy) database of the NASA, hereafter abbreviated to SSE. Several researchers have reported variations in the SSI during the second half of the 20th century, a phenomenon that has come to be known as solar dimming followed by a brightening (Cohen $e t$ al., 2004; Gilgen et al., 1998; Liepert, 2002; Ohmura, 2006; Stanhill and Cohen, 2001; Wild et $a l ., 2005)$. The second purpose of the paper is to study long-term variation of the SSI (19692005) at the sites mentioned in the first part and to extrapolate the findings to the four nations using the selected SSI database. 


\section{Meteosat images}

The Meteosat program, operated by the European Space Agency (ESA) started in 1977. The Meteosat satellites are geostationary spacecrafts which fly at an altitude of about $36,000 \mathrm{~km}$ over the equator, and located close to $0^{\circ}$ longitude. Their primary mission is to generate images of the Earth showing its cloud systems both by day and by night, and to transmit these images to the users in the shortest practical time. Eumetsat (Darmstadt, Germany) is the European organisation for the exploitation of this system and dissemination of the images. The main payload of the first generation of these satellites, from Meteosat-1 up to 7, is the Meteosat Visible and InfraRed Imager (MVIRI) which is a high resolution radiometer with three spectral bands. The visible band (VIS) measures the reflected sunlight in a broadband from $300 \mathrm{~nm}$ to $1100 \mathrm{~nm}$. From the original VIS images, a special set of data, called ISCCPB2, has been set up in the framework of the International Satellite Cloud Climatology Project (ISCCP) (Schiffer and Rossow, 1985), part of the World Climate Research Program (WCRP). This reduced-resolution set is produced according to the following steps (Anonymous 1996):

- firstly, time sampling reduces the frequency of observation to the standard meteorological synoptic 3-h intervals, starting at 0000 UTC. The Earth is scanned by the first series of Meteosat satellites in approximately 25 minutes. An image acquired at, say 1130 UTC is actually acquired between 1130 and 1155 UTC. The time used in the computations is the actual acquisition time for this particular pixel,

- secondly, the higher-resolution visible-channel data are averaged to match the lower resolution of infrared-channel data (i.e. an image of $2500 \times 2500$ pixels with a resolution of $5 \mathrm{~km}$ at nadir),

- thirdly, a spatial sampling is performed by taking 1 pixel over 6 in each direction, starting with the south-easternmost pixel. Thus, two B2 pixels are separated by a gap of approximately $30 \mathrm{~km}$. The value of the corresponding B2 pixel is given by the radiance of the south-easternmost pixel in a $6 \times 6$ pixels square

Eumetsat has an archive of B2 images, starting January 1, 1985. Mines ParisTech purchased part of this archive, from the beginning till the end of 2005. All images of this series are not geometrically superimposable though they should be. We report here these findings for the benefit of all users of B2 images. Four changes are occurring during these years; they consist in 
offset by one B2 pixel for the whole image. Assume a geographical site, defined by its latitude and longitude. To these coordinates correspond a B2 row and a column (line, col) in the 1985 images which constitute the relative reference. We found four periods:

- first period: 1 January 1985 to 18 March 1986, slot 11 included. The corresponding B2 pixel is (line, col),

- second period: 18 March 1986, slot 23, to 12 December 1988. The corresponding B2 pixel is (line, col +1$)$, i.e., a shift to the east of approx. $30 \mathrm{~km}$,

- third period: 13 December 1988 to 15 November 1995, slot 23 included. The corresponding B2 pixel is (line, col), as in the $1^{\text {st }}$ period,

- fourth period: 15 November 1995, slot 30, to 31 December 2005. The corresponding B2 pixel is (line-1, col), i.e. a pixel shift to the north.

Several pioneering works demonstrated the interest of B2 data for producing time-series of daily values of SSI (Ba et al., 2001; Raschke et al., 1987; Tuzet et al., 1984). Lefèvre et al. (2007) found that the combination of B2 images and the method Heliosat-2 of Rigollier et al. (2004) offers enough accuracy for creating a climatological database of the daily mean SSI over large areas with a grid cell of about 5' of arc angle in size (approximately $10 \mathrm{~km}$ at midlatitude). They conclude that such B2 data can be used in a reliable way in producing timeseries of SSI for Europe, Africa and the Atlantic Ocean, except for very high latitudes greater than approximately $65^{\circ}$. The $\mathrm{B} 2$ data set is used to create the database $\mathrm{HC} 1$. As for the database SSE, it is derived from the DX data set of ISCCP (Rossow and Schiffer, 1999) which is itself derived from the $\mathrm{B} 2$ data.

Accurate calibration of the satellite sensors is essential for the computation of the SSI, especially when large time-series are at stake. The ISCCP data set results from the fusion of images from all meteorological geostationary and polar-orbiting satellites and intercalibration of all sources has been performed (Schiffer and Rossow, 1985). As for the HC1 database, the B2 images are calibrated according to the automatic calibration method of Lefèvre et al. (2000); the whole operation procedure is described by Rigollier et al. (2002). There has been many changes in Meteosat sensors from 1985 to 2005 and these changes induce uncertainties. Actually, the above-mentioned authors found out that the impacts of these changes may be kept low using an appropriate method. The calibration method itself leads to uncertainties in 
reflectances that have been estimated to $10 \%$ in relative value (RMSE) by these authors. From the work of Lefèvre et al. (2007), we can compute that the relative uncertainty in irradiance arising from the calibration is approximately $1 \%$ of the clear-sky value.

\section{The databases HelioClim and NASA SSE}

The two databases deliver daily mean of SSI from 1985 to 2005 for $\mathrm{HC} 1$ and 1983 to 2005 for SSE. Approximately three well sunlit B2-images can be exploited per day to compute the instantaneous SSI for these slots - typically, at 9:00, 12:00 and 15:00 UT for satellite nadir.The conversion of B2 digital counts into SSI and further in daily mean of SSI is described by Pinker and Laszlo (1992) for the database SSE and Lefèvre et al. (2007) for the database HC1. In this paper, the databases are taken as they are and we will not detail the methods. Though presenting many differences, both methods have in common the fact that they have a model for the prediction of clear-sky irradiances and another model for the extinction of the radiation due to cloud presence. In the geographical area under concern, the most critical point is the clear-sky model as the skies are often clear, and especially the inputs to the model that describe the aerosols and water vapour optical properties and loading. The method for the SSE exploits the assimilation model MATCH (Model of Atmospheric Transport and Chemistry) of NCAR (The National Center for Atmospheric Research) with inputs from the sensors AVHRR (Advanced High Resolution Radiometer) and MODIS (The Moderate Resolution Imaging Spectroradiometer). The method for $\mathrm{HCl}$ calls upon the Linke turbidity factor, that integrates the effect of aerosols and water vapour (Jacovides et al. 1994). A worldwide climatological database of the Linke turbidity factor for each month and each cell of approx. $10 \mathrm{~km}$ has been set up by Remund et al. (2003) and is freely available at the web site www.soda-is.com.

The HelioClim databases are created and managed by Mines ParisTech (Cros et al., 2004a). The data are accessible via the SoDa Web site (http://www.soda-is.com, Gschwind et al., 2006). The database HC1 comprises the equivalence of 118500 measuring pseudo-stations (the B2 pixels). Each B2 pixel is $5 \mathrm{~km}$ in size at satellite nadir. Given any geographical location, the Web server performs an on-line spatial interpolation using the nine surrounding pseudostations to deliver a time-series of daily mean of SSI for this location (Lefèvre et al. 2007). The release 4 of $\mathrm{HC} 1$ is used in this study. 
The database SSE can be accessed via the SSE web site (http://eosweb.larc.nasa.gov/sse/). Actually, the SSI values are obtained from the Surface Radiation Budget (SRB) portion of NASA's Global Energy and Water Cycle Experiment (GEWEX). The current SRB archive is Release 3.0. The size of the cell is uniformly set to $1^{\circ}$ of arc angle. We use in this study the release 6 of the SSE.

\section{The ground measurements}

Ground measurements were collected for the period 1985 - 2005 for nine stations in Egypt by the Egyptian meteorological authority. All measurements were done with Eppley Precision Spectral Pyranometers (PSP), and the data were manually quality-controlled before delivery. The World Radiation Data Center (WRDC) provided the data for Sidi Bou Said (Tunisia) and Tamanrasset (Algeria). The stations are listed in Table 1 together with the solar radiation climate to which they belong according to Diabaté et al. (2004). Tamanrasset (climate 4) is located on the high Sahara plateau of Ahaggar of elevation larger than $1000 \mathrm{~m}$. The climate is dry and semi-arid (BShw). The sky is usually very clear, with the exception of occurrence of dust winds in June and December. Cairo is one of the largest cities in Africa (approximately 13 millions of inhabitants); it is the seat of industries and the traffic of vehicles is large. Bahtim is a suburb of Cairo. Both stations belong to the climate \# 5 in semi-arid warmer dry climate with a boreal summer dry season (BShs) with a high level of pollution but frequent clear skies. Sidi Barrani, Mersa Matruh and Tahrir are located 1 to $10 \mathrm{~km}$ south of the Mediterranean sea coast in a typical Mediterranean climate with frequent clear skies. Climate \#7 (El Arish) is limited to the arid Sinai Peninsula. The sky is very clear in boreal summer; more cloudy skies are found in November and December. Sidi Bou Said (climate 8) experiences rainy climate with mild winter (Csa). Clear skies are most frequent in June and July. Though both are found along the Mediterranean coast, climate \#8 exhibits lower SSI than \#6. Asyut and El Kharga belong to climate \#12 that comprise desert areas with dry climate (BWh); the sky is often clear and the variation in atmospheric extinction during a year is small. This variation is even smaller for climate \#14 (Aswan) located in the Northern Sahara with a dry desert climate (BWh). 
All the daily data for the period 1985-2005 have been averaged for producing monthly means of SSI. A monthly mean was declared valid only if at least 22 daily valid values were available; otherwise, it was rejected. The same processing was applied to the HC1 and SSE data.

\section{Correcting satellite assessment for altitude}

The computation of the SSI from satellite images calls upon a digital terrain model whose cell size fits that of the pixel. For example, the HC1 database exploits the model TerrainBase whose cell size is 5 minute of arc angle (approximately $10 \mathrm{~km}$ at mid-latitude). This is too large to sufficiently accurate describe changes in altitude in areas of steep relief and large discrepancies can be found between the mean altitude of a cell and the altitude of a particular site within this cell.

These discrepancies have an impact on the results of the comparison of the monthly mean of SSI derived from satellite and that measured by ground instruments because the higher the elevation, the higher the SSI for similar atmospheric conditions. The use of a correction function would help in reducing the discrepancies between the satellite-derived SSI and ground measurements due to difference in altitude and accordingly, would permit to better assess the uncertainty of the satellite-derived SSI in equal conditions. Taking into account the lack of knowledge on the optical constituents of the atmosphere for each day and each site, we have opted for an empirical function. By performing several tens of simulation of the SSI under clear skies by the radiative transfer models libRadtran (Mayer and Kylling 2005) and 6S (Vermote et al. 1997) at different altitudes for different conditions (various solar zenith angle, atmospheric and ground properties), we found an empirical correction function describing the change in clear-sky SSI $I_{c}(z)$ with the altitude $z$, knowing the clear-sky SSI $I_{c}\left(z_{0}\right)$ at an altitude $z_{0}$ :

$$
I_{c}(z)=I_{0} \exp [-\tau(z)]
$$

where $\tau(z)$ expresses the optical thickness of the atmosphere:

$$
\tau(z)=\tau\left(z_{0}\right) \beta^{(z 0-z)}, \beta=1.20
$$

where $\tau\left(z_{0}\right)$ is given by:

$$
\tau\left(z_{0}\right)=-\ln \left(I_{c}\left(z_{0}\right) / I_{0}\right)
$$

where $I_{0}$ is the irradiance measured at the top of the atmosphere. 
We have further investigated the possible application of this correcting function to all skies. Given the SSI for any sky $I$, the clear-sky index $K_{c}$ is defined as:

$$
I(z)=K_{c}(z) I_{c}(z)
$$

The clear-sky index characterizes the actual SSI compared to the clear-sky SSI. The change in irradiance $I$ due to change in altitude $z$ is given by

$$
\partial I / \partial z=K_{c} \partial I_{c} / \partial z+I_{c} \partial K_{c} / \partial z
$$

As previously, libRadtran is used to obtain a series of simulations and compute each term in Eq. 5 in many different conditions. Additional inputs are the optical depth of the clouds and the altitude of their tops and bottoms. We found that for $z$ ranging from $0 \mathrm{~km}$ to $3 \mathrm{~km}, K_{c}$ remains quasi-constant while $I_{c}$ is changing. This means that the change in the SSI $I$ with $z$ in the lower layer of the atmosphere is equal to that of the clear-sky SSI $I_{c}$. The righternmost term in Eq. 5 may be neglected at first order. It results that the correction function (Eqs1-3) may apply in any case.

We now use 17 stations of high quality for which the difference in altitude with that used in $\mathrm{HC} 1$ is greater than $200 \mathrm{~m}$ to validate this empirical approach (Table 2). Such a difference should lead to overestimation (if the difference is positive) and underestimation (if the difference is negative) of SSI in $\mathrm{HC} 1$ when compared to actual measurements. The correction function is applied to the time-series of $\mathrm{HC} 1$ monthly means of SSI. The clear-sky SSI $I_{c}(z)$ is computed with the clear-sky model of Rigollier et al. (2000) corrected by Geiger et al. (2002). Comparison is made between the actual measurements, the original outputs from $\mathrm{HC} 1$, and the corrected ones (Table 3). If the correction is efficient, one expects a decrease in bias; a decrease or stability in RMSD (root mean square difference) as well as in correlation. Benefit of correction is achieved in 13 cases out of 17 (76\% of the cases): the correction in altitude leads to a decrease of the bias. For the four other sites, overestimation by uncorrected $\mathrm{HC} 1$ is observed for site 1 where an underestimation was expected and inversely for sites 9, 12 and 17. For these sites, the cause of the bias between $\mathrm{HC} 1$ and ground station is mostly due to other conditions than difference in altitude. Consequently, no gain can be expected. The correlation coefficient does not change noticeably with the correction. The RMSD remains similar or decrease, except for sites 1 and 17 for which the RMSD increases respectively from 14 to 
$16 \%$ and from 20 to $22 \%$. Similar gains are obtained for daily means of SSI but are not discussed here. Given the number of good cases and the fact that degradation of performance in adverse cases is limited, we conclude that the correction altitude is worth to be applied in a systematic way. From now on, $\mathrm{HCl}$ data means $\mathrm{HCl}$ data corrected for altitude. The correction was not applied to SSE because the mean altitude of the SSE cell is unknown.

\section{Comparing databases to ground measurements}

Table 4 reports on the statistical indicators of the differences between the monthly means of SSI from respectively SSE and ground sites, and $\mathrm{HC1}$ and ground sites. For all sites, the correlation coefficient is large: both databases reproduce well the changes in SSI. Fig. 1 illustrates the case of Sidi Barrani for $\mathrm{HC1}$; coincidence of values is attained quite often but at times, discrepancy may be large as for June 1999. Fig. 2 shows the same case but for SSE: one can see that if the SSE exhibits variations that are in line with the ground measurements (high correlation coefficient), discrepancies are very often significant.

Table 4 shows that the bias differs from site to site but in general its value is small and less than $13 \mathrm{~W} \mathrm{~m}^{-2}$ in absolute value. Exceptions are Tamanrasset (Algeria) and Sidi Barrani (Egypt) for the SSE data, where the bias reaches respectively -17 and $-19 \mathrm{~W} \mathrm{~m}^{-2}$. As a whole, both SSE and $\mathrm{HC} 1$ have a tendency to underestimate the SSI by a few percent with SSE performing slightly better than $\mathrm{HCl}\left(-2 \mathrm{~W} \mathrm{~m}^{-2}\right.$ versus $\left.-4 \mathrm{~W} \mathrm{~m}^{-2}\right)$ but the situation varies from site to site. There is no strong relation between the bias for SSE or HC1 and the solar radiation climatic zone: there are other factors influencing the bias. Cros et al. (2006) indicated that some of physical processes play a role: 1) the solar zenith angle, 2) the difference in location of both satellites that implies that the areas are observed with systematically different viewing angles, and 3) surface type; these reasons may partly explain the bias. However, one may note that SSE overestimates the SSI for polluted urban sites (Bahtim, Cairo) while HC1 underestimates it. This is likely related to the atmospheric turbidity adopted by each model (under-polluted by SSE and over-polluted by HC1). It is also observed that HC1 underestimates the SSI for both desert areas Asyut and El Kharga. The relative standard-deviation (SD) is fairly constant and exhibits values in the range $6-8 \%$ of the mean value for both databases. However, the 
standard-deviation for $\mathrm{HC} 1$ is fairly lower than for SSE. The correlation coefficients values from table 4 are higher for $\mathrm{HC} 1$ than for SSE.

Our findings are very close to those of Lefèvre et al. (2007) for African and European sites for $\mathrm{HCl}$; for El Arish in the period 1994-1995, they found MBE\% and RMSE\% values of $2 \%$ and $6 \%$ respectively, while we find $1 \%$ and $6 \%$ in the period 1986-2005. Average values of $\mathrm{MBE} \%$ in Lefèvre et al. for African and European sites are very close to ours ( $-1 \%$ to $4 \%)$, while average relative values of standard-deviation were higher than our study (11\%). This means that $\mathrm{HC} 1$ performs better in this North African area than elsewhere.

Empirical and semi-empirical methods for assessing the SSI have been developed for decision makers because of the lack of SSI data (Power, 2001). For example, the MBE\% and RMSE\% for the SSI estimated from sunshine fraction in Egypt during the period 1980-1999 are respectively $0.1 \%$ and $6 \%$ (El-Metwally, 2005), while RMSE\% for the SSI estimated from temperature amplitude and cloud ratio is $10 \%$ (El-Metwally, 2004). The performances of SSE and HC1 are similar to those of El-Metwally (2005) and better to those of El-Metwally (2004).

All mixed data were used to study monthly performance for HC1 and SSE databases (Table 5). Statistical performance values show lower errors from April to September (5-7\%) and larger ones for other months because of the increase in cloudiness in winter and autumn. Both databases show low bias except in cloudy seasons: winter and autumn ( -4 to $\left.-7 \mathrm{~W} \mathrm{~m}^{-2}\right)$. Several stations exhibit high bias $\left(-4\right.$ to $\left.-8 \mathrm{~W} \mathrm{~m}^{-2}\right)$ during spring due to the increase of atmospheric extinction because of passing Khamsin depressions coming from Saharan (ElMetwally et al., 2008; El-Wakil et al., 2001, Zakey et al., 2004 and Tadros et al., 2002). As a whole, HC1 underestimates SSI during all months, except May to July; SSE overestimates SSI in summer and underestimates SSI otherwise. SSE show slightly lower bias than HC1 for most months, while HC1 shows lower error (RMSD, SD) for most months (tables 4 and 5, fig. 3). The correlation coefficients are high in winter and autumn and low in spring and summer for both databases. This is due to increasing aerosol amount in spring as mentioned above, however, in summer, high temperature, high transparency and semi-transparent clouds prevail, and the sky is 'dirty' most of the time. This led to a decrease in correlation coefficient in these 
seasons, in spite of this, the error being low in such seasons. This can be noticed also in ElMetwally (2004) in Egypt sites. Thus the systematic error is not evident for high correlation coefficient value since the correlation coefficient is a measure of precision rather than accuracy (Power, 2001). The correlation coefficient values for HC1 are fairly higher than those for SSE for all months.

The validation of both databases is also made at different classes of SSI: low $\left(\right.$ SSI $\left.<100 \mathrm{~W} \mathrm{~m}^{-2}\right)$, medium $\left(100<\mathrm{SSI}<200 \mathrm{~W} \mathrm{~m}^{-2}\right)$ and high $\left(\mathrm{SSI}>200 \mathrm{~W} \mathrm{~m}^{-2}\right)$; results are reported in table $5 . \mathrm{HC} 1$ and SSE show low relative error (RMDS) at high SSI (clear sky) and larger one at both low and medium SSI (cloudy and semi cloudy sky). Error and standard deviation values for all classes are slightly lower for $\mathrm{HC} 1$ than for $\operatorname{SSE}(6-8 \%$ and 7-10\%, respectively). Both databases underestimate medium and high SSI and overestimate low SSI.

We can conclude that both databases SSE and HC1 are suitable for assessing the monthly means of SSI in Northern Africa. They offer a high correlation with ground measurements, little bias and standard-deviation. Consequently, one can map the SSI from these databases and use such maps for applications in solar energy. These databases have also the capability of reproducing the time-series of monthly values fairly accurately. They can be used to assess long-term variations of SSI. In this study, we find that HC1 exhibits a smaller scattering of data compared to ground measurements (smaller standard-deviation) than the SSE. A small standard-deviation is important when looking at long-term variations and we select the $\mathrm{HC} 1$ in the following.

\section{Long-term variations}

The variation of the yearly mean of SSI is discussed for different sites with long range of continue records Egypt in addition to Sidi Bou Said (Tunisia) and Tamanrasset (Algeria) for limited periods( 1985-2000 and 1995-2005 respectively).

The long records (36 years) at Cairo, Bahtim, Kharga and Aswan as shown in Fig. 4 indicate the initial dimming and recent recovery; this result was noticed by Ohmura (2006) for several sites in Egypt. He also noticed that the time of the recovery was somewhat delayed in 
comparison with other regions such as Central Africa and Pretoria. The other sites for 20-25 years (short records): Sidi Barrani, El Arish, Mersa Matruh, Aswan and Asyut show the same phenomena than long records. The mean curve shows the SSI reaching its peak in the late of 1960 s and decreasing from the early of 1970 s to the early of 1990 s. Slightly recovery can be noticed in the mid of 1990s but is small (see Fig 5). Generally, the SSI at all sites continued to decrease from 1970s up to present, the range of dimming is $\sim 17-44 \mathrm{~W} \mathrm{~m}^{-2}$ for long record sites and $\sim 8-27 \mathrm{~W} \mathrm{~m}^{-2}$ for short record (the mean value for all sites is $\sim 25 \mathrm{~W} \mathrm{~m}^{-2}$ ). The dimming values for each site are presented in table 7. One may note exceptions in Sidi Barrani and Tamanrasset which show negative values: in both sites, the SSI increases in the recent years.

The mean of normalized values with respect to the long-term means at each site are presented in Fig. 5. This figure confirms the results shown in Fig. 4. The SSI continued to decrease from the early of $1970 \mathrm{~s}$ up to present, by 0.17 , which corresponds to a decrease of $\sim 35 \mathrm{~W} \mathrm{~m}^{-2}$ over 36 years, a result close to that of Ohmura (2006) found in Egypt sites. Omran (2000) found that decline for three sites: Mersa Matruh, Cairo and Aswan for 10 years for the period from 1984 to 1994 are $\sim 15,16$ and $21 \mathrm{~W} \mathrm{~m}^{-2}$ respectively, while we find $\sim 14,45$ and $25 \mathrm{~W} \mathrm{~m}^{-2}$ respectively (table 7). He attributed the decline at Cairo and Aswan to the increase of atmospheric aerosols. In another study, Robaa (2008) found that the SSI received at Cairo during the non-urbanized period (1969-1973) highly exceeded the SSI received during the recent urbanized period (1999-2003) for all months of the year, and the annual mean of the relative reduction is $\sim 18 \%$. These findings support the hypothesis of Omran. A similar conclusion was reached by Jacovides et al. (1994) who showed that the trends in irradiance (decrease) and in turbidity (increase) observed in Athens (Greece) reflect the rapid urbanization and industrialization of the city.

The mean rate global radiation and decline in solar radiation during four decades for each site are presented in Table 8 . The negative values mean decline, while positive mean ascending in solar radiation for each decade. All sites decline (negative values) in SSI at 1970s and 1980s except Kharga in 1970s and Sidi Barrani in 1980s, while all sites decline in SSI at 2000s. However, at 1990s, the recovery can be noticed at the late 199s as in Fig. 5 for more than half sites $\left(\sim 2-14 \mathrm{~W} \mathrm{~m}^{-2}\right.$, with mean rate of change per year of 1-3 $\left.\mathrm{W} \mathrm{m}^{-2}\right)$. Therefore, higher decline 
can be noticed at Cairo and Bahtim at 1970s $\left(\sim 20 \mathrm{~W} \mathrm{~m}^{-2}\right.$, with mean rate of change per year $\sim 2 \mathrm{~W} \mathrm{~m}^{-2}$ ) that may be due to increase in urbanization at both sites. Also, Cairo and Bahtim along with Kharga, Tahrir, Asyut and Aswan exhibit higher decline in 1980s ( 12-19 $\mathrm{W} \mathrm{m}^{-2}$, with mean rate of change per year of $\sim 1-2 \mathrm{~W} \mathrm{~m}^{-2}$ ) than other sites. In $2000 \mathrm{~s}$ all sites recorded decline; Asyut and Sidi Barrani have the highest decline $\left(\sim 20 \mathrm{~W} \mathrm{~m}^{-2}\right.$ and $\sim 32 \mathrm{~W} \mathrm{~m}^{-2}$, with rate of change per year of $\sim 4 \mathrm{~W} \mathrm{~m}^{-2}$ and $\sim 6 \mathrm{~W} \mathrm{~m}^{-2}$, respectively). Generally, mean value for all sites shows slight decline at $1970 \mathrm{~s}$ and $2000 \mathrm{~s}\left(\sim 2 \mathrm{~W} \mathrm{~m}^{-2}\right.$ and $\sim 6 \mathrm{~W} \mathrm{~m}^{-2}$, with mean rate of change per year of $\sim 0.2 \mathrm{~W} \mathrm{~m}^{-2}$ and $\sim 1.2 \mathrm{~W} \mathrm{~m}^{-2}$, respectively), while a high decline is observed at $1980 \mathrm{~s}$ $\left(\sim 16 \mathrm{~W} \mathrm{~m}^{-2}\right.$, with rate of change per year of $\left.\sim 2 \mathrm{~W} \mathrm{~m}^{-2}\right)$; however the recovery can be noticed in $1990 \mathrm{~s}\left(\sim 7 \mathrm{~W} \mathrm{~m}^{-2}\right.$, with rate of change per year $\left.\sim 1 \mathrm{~W} \mathrm{~m}^{-2}\right)$.

Figures 4 and 5 exhibit non-stationnarities both in time and space. One possible explanation maybe the 11-year solar cycle (Varotsos and Cracknell 2004). If it were the sole explanation, spatial stationnarity would be observed which is not the case. Other causes may be changing cloud cover, increasing manmade aerosols and the lowering of atmospheric transparency following explosive volcanic eruptions (Norris and Wild 2007; Pinker et al. 2005). A number of recent studies attribute changes in sunshine duration to changes in aerosol loading (Kaiser and Qian 2002; Liang and Xia 2005; Che et al. 2005; Qian et al. 2006). Aerosols do not only scatter sunlight and enhance planetary shortwave albedo-a phenomenon known as "aerosol direct effect"-but also act as cloud condensation nuclei, change cloud properties and produce essential increase in cloud albedo-a phenomenon referred to as "aerosol indirect effect" (Quaas et al. 2004). Varotsos et al. $(2005,2006)$ observe that the variations in space and time of the detrended fluctuations in aerosol concentration obey a power-law whose exponent varies from site to site.

Figure 6 shows the range of dimming for the area under concern and the period 1985-2005. This map is constructed from HC1 database. As expected from the analysis of the measuring sites, values are mostly positive; only a very few spots of values close to 0 can be found (black and dark grey). It means that the area as a whole experiences dimming for the period. There is no clear structure in the map; the field is patchy. This may be due to the noise affecting $\mathrm{HC} 1$, expressed as the standard-deviation (SD) in previous tables. However, one notes that the range 
of dimming increases from south to north as a whole. As discussed earlier, this may be due to the transportation of sand dust from Sahel northwards. Wild et al. (2005) linked the dimming to the increase in cloud cover and aerosol loading for that period. Another explanation for several areas, especially along the Nile River, is the increase of urbanization and thus of aerosol emission leading to an increase in atmospheric extinction. All phenomena are not exclusive and may concurrently apply.

\section{Conclusions}

This study supports previous results that demonstrate that it is possible to accurately derive the SSI from geostationary meteorological satellites, even with a coarse spatial resolution. The two databases assessed exhibit similar and good performances. The bias is lower for SSE than for $\mathrm{HC} 1$, as a whole; inversely, $\mathrm{HC} 1$ exhibits a smaller scattering of data compared to ground measurements (smaller standard-deviation) than the SSE.

The SSI can be mapped from these databases and such maps can be used for applications in solar energy. These databases have also the capability of reproducing the time-series of monthly values fairly accurately. They can be used to assess long-term variations of SSI, especially $\mathrm{HC} 1$ because of its lower standard-deviation.

These long-term variations show that these four nations experience dimming as a whole. Detailed analyses of the range of dimming at sites with long-term records and of its spatial distribution have been performed. It has been found that the analysis of SSI derived from satellite supports the findings for the individual sites. Several phenomena may explain the dimming. One is the transportation of sand dust northwards from the Sahel; another one is the increase in urbanization and a third one is the increase in cloud cover and aerosol loading.

\section{Acknowledgements}

The help of the archives Department of Eumetsat is acknowledged for the provision of several years of Meteosat images. The authors thank the Egyptian Meteorological Authority and the World Radiation Data Centre for the provision of ground measurements. For the French team, this study as been partly performed under the project MESoR "management and exploitation 
of the solar resource knowledge" funded by the European Commission and under a grant of the French Agency for Environment ADEME under the auspices of the Task SHC 36 of the International Energy Agency.

\section{References}

Abdel Wahab, M., 1985, Simple model for estimating global radiation. Solar \& Wind Technology, 2, pp.69-71.

Abdel Wahab, M., 1987, Predicting global radiation from a satellite and a numerical model: a cooperative study. Solar \& Wind Technology, 4, pp. 319-323.

Anonymous, 1996, The Meteosat Archive, Format Guide No. 3, ISCCP Data Set (IDS) in OpenMTP Format, February 1996, EUM FG3, Rev. 1.0, Published by Eumetsat, Darmstadt, Germany.

Ba, M., Nicholson, S., and Frouin, R., 2001, Satellite-derived surface radiation budget over the African continent. Part II: Climatologies of the various components. Journal of Climate, 14, pp. 60-76.

Cano, D., Monget, J.M., Albuisson, M., Guillard, H., Regas, N., and Wald, L., 1986, A method for the determination of the global solar radiation from meteorological satellite data. Solar Energy, 37, pp. 31-39.

Che, H.Z., Shi, G.Y., Zhang, X.Y., Arimoto, R., Zhao, J.Q., Xu, L., Wang, B., and Chen, Z. H., 2005, Analysis of 40 years of solar radiation data from China, 1961-2000. Geophysical Research Letters, 32, pp. L06803.

Cohen, S., Liepert, B. and Stanhill, G., 2004, Global dimming comes of age. EOS Transactions, 38: pp. 362-363.

Cros, S., Albuisson, M., Lefèvre, M., Rigollier, C., and Wald, L., 2004a. HelioClim: a longterm database on solar radiation for Europe and Africa. In Proceedings of Eurosun 2004, published by PSE GmbH, Freiburg, Germany, pp. 916-920(3).

Cros, S., Mayer, D., and Wald, L., 2004b, The Availability of Irradiation Data. Report IEAPVPS T2-04: 2004, International Energy Agency, Vienna, Austria, 29 p.

Cros, S., Albuisson, M., Wald, L., 2006. Simulating Meteosat-7 broadband radiances using two visible channels of Meteosat-8. Solar Energy, 80, pp. 361-367. 
Diabaté, L., Blanc, Ph., and L. Wald, 2004, Solar radiation climate in Africa. Solar Energy, 76, 733-744.

Diabaté, L., Demarcq, H., Michaud-Regas, N., and Wald, L., 1988, Estimating incident solar radiation at the surface from images of the Earth transmitted by geostationary satellites: the Heliosat Project. International Journal of Solar Energy, 5, pp. 261-278.

Diabaté, L., Moussu, G., and Wald, L., 1989, Description of an operational tool for determining global solar radiation at ground using geostationary satellite images. Solar Energy, 42, pp. 201-207.

Drews, A., de Keizer, A.C., Beyer, H.G., Lorenz, E., Betcke, J., van Sark, W. G. J. H. M., Heydenreich, W., Wiemken, E., Stettler, S., Toggweiler, P., Bofinger, S., Schneider, M., Heilscher, G., and Heinemann, D., 2007. Monitoring and remote failure detection of grid-connected PV systems based on satellite observations. Solar Energy, 81, pp. 548-564, doi:10.1016/j.solener.2006.06.019.

El-Metwally, M., 2004, Simple new methods to estimate global solar radiation based on meteorological data in Egypt. Atmospheric Research, 69, pp. 217-239.

El-Metwally, M., 2005, Sunshine and global solar radiation estimation at different sites in Egypt. Journal of Atmospheric and Solar-Terrestrial Physics, 67, pp. 1331-1342.

El-Metwally, M., Alfaro, S.C., Abdel Wahab, M. and Chatenet, B., 2008, Aerosol characteristics over urban Cairo: Seasonal variations as retrieved from Sun photometer measurements. Journal of Geophysical Research., 113, pp. D14219, doi:10.1029/2008JD009834.

El-Wakil, S.A., El-Metwally, M. and Gueymard, C., 2001, Atmospheric turbidity of urban and desertic areas of the Nile Basin in the aftermath of Mt. Pinatubo`s eruption. Theoretical and Applied Climatology, 68, pp. 89-108.

ESRA, 2000, European Solar Radiation Atlas, fourth ed., includ. CD-ROM. Edited by Greif, J., and Scharmer, K., Scientific advisors: Dogniaux, R., Page, J. K., Authors: L. Wald, L., Albuisson, M., Czeplak, G., Bourges, B,. Aguiar, R., Lund, H., Joukoff, A., Terzenbach, U., Beyer, H.G. and Borisenko. E.P., Published for the Commission of the European Communities by Presses de l'Ecole, Ecole des Mines de Paris, Paris, France.

Geiger, M., Diabaté, L., Ménard, L., and Wald, L., 2002, A web service for controlling the quality of measurements of global solar irradiation. Solar Energy, 73, pp. 475-480. 
Gilgen, H., Wild, M. and Ohmura, A., 1998, Means and trends of shortwave irradiance at the surface estimated from global energy balance archive data. Journal of Climate, 11, pp. 2042-2061.

Gschwind, B., Ménard, L., Albuisson, M. and Wald, L., 2006, Converting a successful research project into a sustainable service: the case of the SoDa Web service. Environmental Modelling and Software, 21, pp.1555-1561, doi:10.1016/j.envsoft.2006.05.002.

Hammer, A., Heinemman, D., Hoyer, C., Kuhlemann, R., Lorenz, E., Mueller, R., and. Beyer, H.G, 2003, Solar energy assessment using remote sensing technologies. Remote Sensing of Environment, 86, pp. 423-432.

Ibrahim, S.M.A., 1985, Predicted and measured global solar radiation in Egypt. Solar Energy, 35, pp. 185-188.

Imageen, Z., 2004. Solar energy in progress and future research trends. Progress in Energy and Combustion Science, 30, pp. 367-416.

Jacovides, C. P., Varotsos, C., Kaltsounides, N.A., Petrakis, M. and Lalas, D.P., 1994, Atmospheric turbidity parameters in the highly polluted site of Athens basin. Renewable Energy, 4, pp. 465-470.

Kaiser, D.P., and Qian, Y., 2002. Decreasing trends in sunshine duration over China for 19541998: Indication of increased haze pollution? Geophysical Research Letters, 29, pp. 2042 .

Labed, S., and Lorenzo, E., 2004. The impact of solar radiation variability and data discrepancies on the design of PV systems. Renewable Energy, 29, pp. 1007-1022.

Langniss, O., and Ince, D., 2004. Solar water heating: A viable industry in developing countries. Refocus, 5, pp. 18-21.

Lefèvre, M., Bauer, O., Iehle, A. and Wald, L., 2000, An automatic method for the calibration of time-series of Meteosat images. International Journal of Remote Sensing, 21, 5, pp. 1025-1045.

Lefèvre, M., Diabaté, L., and Wald, L., 2007, Using reduced data sets ISCCP-B2 from the Meteosat satellites to assess surface solar irradiance. Solar Energy, 81, 240-253, doi:10.1016/j.solener.2006.03.008. 
Liang, F. and Xia, X.A., 2005, Long-term trends in solar radiation and the associated climatic factors over China for 1961-2000. Annales Geophysicae, 23, pp. 2425-2432.

Liepert, B, 2002, Observed reductions of surface solar radiation at sites in the United States and worldwide from 1961 to 1990. Geophysical Research Letters, 29, pp. 1421, doi:10.1029/2002GL014910.

Mayer, B. and Kylling, A., 2005, Technical note: The libRadtran software package for radiative transfer calculations - description and examples of use. Atmospheric Chemistry and Physics, 5, pp. 1855-1877.

Norris, J. R., and M. Wild, 2007, Trends in aerosol radiative effects over Europe inferred from observed cloud cover, solar "dimming," and solar "brightening". Journal of Geophysical Research, 112, pp. D08214, doi:10.1029/2006JD007794.

Ohmura, A., 2006, Observed long-term variations of solar irradiance at the earth's surface. Space Science Review, 125, pp. 111-128.

Omran, M.A., 2000, Analysis of solar radiation over Egypt. Theoretical and Applied Climatology, 67, pp. 225-240.

Perez, R., Aguiar, R., Collares-Pereira, M., Dumortier, D., Estrada-Cajigal, V., Gueymard, C., Ineichen, P., Littlefair, P., Lund, H., Michalsky, J., Olseth, J., Renne, D., Rymes, M., Skartveit, A., Vignola, F. and Zelenka, A., 2001, Solar resource assessment: A review. Solar energy - the state of the art. No. ISBN 1902916239 in ISES position papers.(pp. 497- 562). London: James and James Science Publishers.

Perez, R., Seals, R. and Zelenka, A., 1997, Comparing satellite remote sensing and ground network measurements for the production of site/time specific irradiance data. Solar Energy, 60, pp. 89-96.

Pinker, R. T., Zhang, B., and Dutton, E. G., 2005. Do satellites detect trends in surface solar radiation? Science, 308, pp. 850-854.

Power, C., 2001, Estimating clear sky beam irradiation from sunshine duration. Solar Energy, 71, pp. 217- 224 .

Pinker, R.T., and Laszlo, I., 1992, Modeling surface solar irradiance for satellite applications on a global scale. Journal of Applied Meteorology, 31, pp. 194-211. 
Qian, Y., Kaiser, D.P., Leung, L.R. and Xu, M., 2006, More frequent cloud-free sky and less surface solar radiation in China from 1955 to 2000. Geophysical Research Letters, 33, pp. L01812.

Quaas, J., Boucher, O., Dufresne, J.L. and. Le Treut, H., 2004, Impacts of greenhouse gases and aerosol direct and indirect effects on clouds and radiation in atmospheric GCM simulations of the 1930-1989 period. Climate Dynamics, 23, pp. 779-789.

Raschke, E., Gratzki, A. and Rieland, M., 1987, Estimates of global radiation at the ground from the reduced data sets of the International Satellite Cloud Climatology Project. Journal of Climate, 7, pp. 205-213.

Remund, J., Wald, L., Lefèvre, M., Ranchin, T., and Page, J., 2003, Worldwide Linke turbidity information. In: Proceedings of ISES Solar World Congress, 16-19 June 2003, Goeteborg, Sweden, CDROM published by International Solar Energy Society

Rigollier, C., Bauer, O., and Wald, L., 2000, On the clear sky model of the 4th European Solar Radiation Atlas with respect to the Heliosat method. Solar Energy, 68 (1), pp. 33-48.

Rigollier, C., Lefèvre, M., Blanc, Ph. and Wald, L., 2002, The operational calibration of images taken in the visible channel of the Meteosat-series of satellites. Journal of Atmospheric and Oceanic Technology, 19, pp. 1285-1293.

Rigollier, C., Lefèvre, M. and Wald, L., 2004, The method Heliosat-2 for deriving shortwave solar radiation from satellite images. Solar Energy, 77(2), pp.159-169.

Robaa, S. M, 2006, A study of solar radiation climate at Cairo urban area, Egypt and its environs. International Journal of Climatology, 26: pp. 1913-1928.

Rossow, W.B. and Schiffer, R., 1999, Advances in understanding clouds from ISCCP. Bulletin of American Meteorological Society, 80, pp. 2261-2287.

Schiffer, R., and Rossow, W.B., 1985, ISCCP global radiance data set: a new resource for climate research. Bulletin of American Meteorological Society, 66, pp. 1498-1503.

Smyth, M., Eames, P. C. and Norton, B., 2006. Integrated collector storage solar water heaters. Renewable and Sustainable Energy Reviews, 10, pp. 503-538.

SWERA, 2006. http://swera.unep.net/swera.

Stanhill, G. and Cohen, S., 2001, Global dimming: a review of the evidence for a widespread and significant reduction in global radiation with discussion of its probable causes and 
possible agricultural consequences. Agricultural and Forest Meteorology, 107, pp.255278.

Tadros, M.T.Y., El-Metwally, M., and Hamed, A. B., 2002, Determination of Angstrom coefficients from spectral aerosol optical depth at two sites in Egypt. Renewable Energy 27, pp. 621-645.

TerrainBase, 1995. Worldwide digital terrain data, Documentation Manual, CD-ROM Release 1.0, April 1995, NOAA, National Geophysical Data Center, Boulder, CO, USA.

Tuzet, A., Möser, W., and Raschke, E., 1984, Estimating global solar radiation at the surface from Meteosat data in the Sahel region. Journal of Atmospheric Research, 18, pp. 3139.

Varotsos, C., and Cracknell, A. P., 2004, New features observed in the 11-year solar cycle. International Journal of Remote Sensing, 25, pp. 2141-2157.

Varotsos, C., Ondov, J. M. and Efstathiou, M., 2005, Scaling properties of air pollution in Athens, Greece and Baltimore, Maryland. Atmospheric Environment, 39, pp. 40414047.

Varotsos, C., Ondov, J.M., Cracknell, A.P., Efstathiou, M.N., and Assimakopoulos, M.N., 2006, Long-range persistence in global aerosol index dynamics. International Journal of Remote Sensing, 27, pp. 3593-3603.

Vermote, E., Tanré, D., Deuzé, J.L., Herman, M., and Morcrette, J.J., 1997, Second simulation of the satellite signal in the solar spectrum (6S), 6S: An overview. IEEE Transactions on Geoscience and Remote Sensing, 35, pp. 675-686.

Wild, M., Gilgen, H., Roesch, A., Ohmura, A., Long, C. N., Dutton, E. G., Forgan, B., Kallis, A., Russak, V. and Tsvetkov, A., 2005, From dimming to brightening: Decadal changes in solar radiation at earth's surface. Science, 308, pp. 847-850.

Zakey, A. S., M. M. Abdel Wahab, and Makar, P.A,. 2004, Atmospheric turbidity over Egypt, Atmospheric Environment, 38, pp.1579-1591. 


\section{TABLE CAPTIONS}

Table 1. List of the stations used for the period 1985-2005. Climate number is that from Diabaté et al. (2004).

Table 2. Stations used for validation of the altitude correction function. $z g$ is the altitude of the station and $\mathrm{zHC}$ the altitude used in the $\mathrm{HC} 1$ database.

Table 3. Performance of the altitude correction for monthly means of SSI. corrHC1 means corrected HC1. RMSD means root mean square difference.

Table 4. Statistical performance for databases (HC1 and SSE) at all sites used in the period from 1985 to 2005 . The difference is made between the satellite-derived SSI and the measured one. "All mixed" means that all sites have the same weight. RMSD means root mean square difference, SD stands for standard-deviation.

Table 5. As in table 4 but for monthly mean of SSI for all data used mixed together

Table 6. As in table 4 but for three classes (low, medium and high) of SSI for all mixed data used.

Table 7. Range of dimming $\left(\mathrm{W} \mathrm{m}^{-2}\right)$ for record dataset for each site and the mean rate of annual change in yearly means of SSI $\left(\mathrm{W} \mathrm{m}^{-2}\right.$ year $\left.^{-1}\right)$ per all record dataset for each site.

Table 8. Mean annual rate of change in yearly means of SSI ( $\mathrm{W} \mathrm{m}^{-2}$ year $\left.^{-1}\right)$ and decline in SSI for four decades for each site. 


\begin{tabular}{lcccccc}
\hline Station name & WMO id. & Latitude & Longitude & Altitude $(\mathrm{m})$ & Country & Climate number \\
\hline Tamanrasset & 60680 & 22.80 & 5.43 & 1364 & Algeria & 4 \\
Bahtim & 62369 & 30.13 & 31.25 & 17 & Egypt & 5 \\
Cairo & 62371 & 30.08 & 31.28 & 26 & Egypt & 5 \\
Sidi Barrani & 62301 & 31.60 & 26.00 & 26 & Egypt & 6 \\
Mersa Matruh & 62306 & 31.33 & 27.22 & 38 & Egypt & 6 \\
Tahrir & 62345 & 30.65 & 30.70 & 19 & Egypt & 6 \\
El Arish & 62337 & 31.08 & 33.82 & 32 & Egypt & 7 \\
Sidi Bou Said & 60715 & 36.87 & 10.23 & 127 & Tunisia & 8 \\
Asyut & 62392 & 27.20 & 31.17 & 52 & Egypt & 12 \\
Kharga & 62435 & 25.45 & 30.53 & 70 & Egypt & 12 \\
Aswan & 62414 & 23.97 & 32.78 & 192 & Egypt & 14 \\
\hline
\end{tabular}

Table 1. 


\begin{tabular}{|c|c|c|c|c|c|}
\hline Site & Station & Country & $\begin{array}{c}\text { Altitude } \mathrm{z}(\mathrm{m}) \\
\text { station / HC1 }\end{array}$ & $\mathrm{z}_{\mathrm{HC}}-\mathrm{z}_{\mathrm{g}}(\mathrm{m})$ & $\begin{array}{c}\text { Latitude / longitude } \\
\left({ }^{\circ}\right)\end{array}$ \\
\hline 1 & Sonnblick & Austria & $3106 / 2166$ & -940 & $47.05 / 12.95$ \\
\hline 2 & Sofia Obs. & Bulgaria & $586 / 788$ & 202 & $42.82 / 23.38$ \\
\hline 3 & Zagreb & Croatia & $123 / 515$ & 392 & $45.82 / 16.03$ \\
\hline 4 & Churanov & Czech Republic & $1122 / 776$ & -346 & $49.07 / 13.62$ \\
\hline 5 & Tbilisi & Georgia & $490 / 910$ & 420 & $41.68 / 44.95$ \\
\hline 6 & Brocken-Harz & Germany & $1142 / 412$ & -670 & $51.80 / 10.62$ \\
\hline 7 & Hohenpeissenberg & Germany & $990 / 708$ & -282 & $47.80 / 11.02$ \\
\hline 8 & Arta & Greece & $10 / 292$ & 282 & $39.17 / 21.00$ \\
\hline 9 & Valentia Obs. & Ireland & $9 / 301$ & 292 & $51.93 /-9.75$ \\
\hline 10 & Bolzano & Italy & $241 / 984$ & 743 & $46.47 / 11.33$ \\
\hline 11 & Angra do Heroismo & Portugal & $74 / 300$ & 226 & $38.67 /-27.22$ \\
\hline 12 & Madrid-universidad & Spain & $664 / 968$ & 304 & $40.45 /-2.28$ \\
\hline 13 & Corvatsch & Switzerland & 3315 / 2233 & -1082 & $46.42 / 9.82$ \\
\hline 14 & Davos & Switzerland & $1592 / 1818$ & 226 & $46.80 / 9.82$ \\
\hline 15 & La Dole & Switzerland & $1670 / 1232$ & -438 & $46.43 / 6.10$ \\
\hline 16 & Saentis & Switzerland & $2490 / 1126$ & -1364 & 47.25 / 9.35 \\
\hline 17 & Locarno-Monti & Switzerland & $366 / 759$ & 393 & $46.17 / 8.78$ \\
\hline
\end{tabular}

Table 2. 


\begin{tabular}{ccccccc}
\hline Site & $\begin{array}{c}\text { Number } \\
\text { of } \\
\text { samples }\end{array}$ & $\begin{array}{c}\text { Mean } \\
\text { measured value } \\
\left(\mathrm{Wm}^{-2}\right)\end{array}$ & $\begin{array}{c}\text { Mean }\left(\mathrm{Wm}^{-2}\right) \\
\mathrm{HC} 1 / \mathrm{corrHC} 1\end{array}$ & $\begin{array}{c}\text { Bias }\left(\mathrm{Wm}^{-2}\right) \\
\mathrm{HC1} / \\
\text { corrHC1 }\end{array}$ & $\begin{array}{c}\text { RMSD } \\
\left(\mathrm{W} m^{-2}\right)\end{array}$ & $\begin{array}{c}\text { Correlation } \\
\text { coefficient }\end{array}$ \\
\hline 1 & 57 & 163.8 & $167.9 / 173.9$ & $4.1 / 10.1$ & $23.6 / 26.2$ & $0.943 / 0.943$ \\
2 & 94 & 130.0 & $161.0 / 159.1$ & $31.0 / 29.1$ & $38.1 / 36.4$ & $0.960 / 0.960$ \\
3 & 27 & 129.0 & $134.0 / 130.2$ & $5.0 / 1.3$ & $13.3 / 13.4$ & $0.989 / 0.990$ \\
4 & 104 & 119.0 & $112.6 / 115.2$ & $-6.3 /-3.7$ & $13.5 / 12.5$ & $0.983 / 0.983$ \\
5 & 70 & 139.8 & $145.7 / 142.1$ & $5.9 / 2.3$ & $30.4 / 30.5$ & $0.938 / 0.938$ \\
6 & 69 & 105.6 & $103.2 / 108.2$ & $-2.4 / 2.6$ & $16.3 / 15.7$ & $0.974 / 0.974$ \\
7 & 100 & 134.1 & $131.1 / 133.3$ & $-2.9 /-0.8$ & $11.5 / 11.3$ & $0.986 / 0.986$ \\
8 & 76 & 150.8 & $155.7 / 152.3$ & $4.9 / 1.5$ & $18.6 / 17.6$ & $0.973 / 0.973$ \\
9 & 30 & 124.9 & $110.2 / 108.2$ & $-14.7 /-16.8$ & $17.1 / 18.9$ & $0.990 / 0.989$ \\
10 & 51 & 135.8 & $143.4 / 136.4$ & $7.6 / 0.5$ & $14.9 / 14.1$ & $0.985 / 0.985$ \\
11 & 53 & 132.1 & $184.1 / 181.8$ & $52.1 / 49.7$ & $57.3 / 54.9$ & $0.972 / 0.972$ \\
12 & 36 & 183.6 & $183.0 / 179.9$ & $-0.6 /-3.7$ & $11.0 / 12.0$ & $0.992 / 0.992$ \\
13 & 105 & 175.2 & $158.3 / 165.1$ & $-16.9 /-10.2$ & $25.8 / 22.8$ & $0.962 / 0.960$ \\
14 & 105 & 152.5 & $156.5 / 154.6$ & $4.1 / 2.4$ & $19.0 / 18.5$ & $0.966 / 0.967$ \\
15 & 36 & 131.3 & $128.8 / 131.8$ & $-2.5 / 0.5$ & $17.9 / 18.7$ & $0.976 / 0.976$ \\
16 & 105 & 148.4 & $138.1 / 147.8$ & $-10.3 /-0.6$ & $19.0 / 18.5$ & $0.973 / 0.972$ \\
17 & 105 & 145.5 & $123.2 / 119.7$ & $-22.3 /-25.8$ & $29.6 / 32.6$ & $0.970 / 0.970$ \\
\hline
\end{tabular}

Table 3. 


\begin{tabular}{|c|c|c|c|c|c|c|}
\hline Station & Ground $\left(\mathrm{W} \mathrm{m}^{-2}\right)$ & $\mathrm{Nb}$ samples & $\operatorname{Bias}\left(\mathrm{W} \mathrm{m}^{-2}\right)$ & $\operatorname{RMSD}\left(\mathrm{W} \mathrm{m}^{-2}\right)$ & $\mathrm{SD}\left(\mathrm{W} \mathrm{m}^{-2}\right)$ & Correl \\
\hline \multirow{2}{*}{ Tamanrasset } & \multirow{2}{*}{264} & \multirow{2}{*}{132} & SSE: $-17(-7 \%)$ & SSE: $22(8 \%)$ & SSE: 13 & SSE: 0.960 \\
\hline & & & $\mathrm{HC} 1:-7(-3 \%)$ & $\mathrm{HC} 1: 16(6 \%)$ & HC1: 15 & HC1: 0.945 \\
\hline \multirow{2}{*}{ Bahtim } & \multirow{2}{*}{218} & \multirow{2}{*}{251} & SSE: $5(2 \%)$ & SSE: $16(7 \%)$ & SSE: 15 & SSE: 0.977 \\
\hline & & & $\mathrm{HC} 1:-13(-6 \%)$ & HC1: $19(9 \%)$ & HC1: 14 & HC1: 0.979 \\
\hline \multirow[t]{2}{*}{ Cairo } & \multirow{2}{*}{214} & \multirow{2}{*}{251} & SSE: $9(4 \%)$ & SSE: $15(7 \%)$ & SSE: 12 & SSE: 0.984 \\
\hline & & & HC1: $-9(-4 \%)$ & $\mathrm{HC} 1: 16(7 \%)$ & HC1: 13 & HC1: 0.982 \\
\hline \multirow{2}{*}{ Sidi Barrani } & \multirow{2}{*}{225} & \multirow{2}{*}{251} & SSE: $-19(-9 \%)$ & SSE: $29(13 \%)$ & SSE: 22 & SSE: 0.962 \\
\hline & & & $\mathrm{HC} 1: 3(1 \%)$ & HC1: $17(7 \%)$ & HC1: 16 & HC1: 0.979 \\
\hline \multirow{2}{*}{ Mersa Matruh } & \multirow{2}{*}{225} & \multirow{2}{*}{251} & SSE: $-6(-3 \%)$ & SSE: $18(8 \%)$ & SSE: 17 & SSE: 0.978 \\
\hline & & & $\mathrm{HC} 1: 5(2 \%)$ & $\mathrm{HC} 1: 16(7 \%)$ & $\mathrm{HC1}: 15$ & $\mathrm{HC} 1: 0.983$ \\
\hline \multirow{2}{*}{ Tahrir } & \multirow{2}{*}{215} & \multirow{2}{*}{138} & SSE: $6(3 \%)$ & SSE: $17(8 \%)$ & SSE: 16 & SSE: 0.986 \\
\hline & & & HC1: $-9(-4 \%)$ & $\mathrm{HC} 1: 15(7 \%)$ & HC1: 12 & HC1: 0.987 \\
\hline \multirow{2}{*}{ El Arish } & \multirow{2}{*}{227} & \multirow{2}{*}{239} & SSE: $10(4 \%)$ & SSE: $18(8 \%)$ & SSE: 15 & SSE: 0.983 \\
\hline & & & $\mathrm{HC} 1: 1(1 \%)$ & $\mathrm{HC} 1: 13(6 \%)$ & HC1: 13 & HC1: 0.989 \\
\hline \multirow{2}{*}{ Sidi Bou Said } & \multirow{2}{*}{194} & \multirow{2}{*}{178} & SSE: $-6(-3 \%)$ & SSE: $12(6 \%)$ & SSE: 11 & SSE: 0.991 \\
\hline & & & $\mathrm{HC1}: 7$ (3\%) & HC1: $13(7 \%)$ & HC1: 11 & HC1: 0.993 \\
\hline \multirow{2}{*}{ Asyut } & \multirow{2}{*}{243} & \multirow{2}{*}{251} & SSE: $3(1 \%)$ & SSE: $20(8 \%)$ & SSE: 20 & SSE: 0.966 \\
\hline & & & $\mathrm{HCl}:-7(-3 \%)$ & $\mathrm{HC} 1: 18(8 \%)$ & HC1: 18 & HC1: 0.962 \\
\hline \multirow{2}{*}{ El Kharga } & \multirow{2}{*}{256} & \multirow{2}{*}{251} & SSE: $-7(-3 \%)$ & SSE: $15(6 \%)$ & SSE: 14 & SSE: 0.976 \\
\hline & & & HC1: $-8(-3 \%)$ & HC1: $15(6 \%)$ & HC1: 13 & HC1: 0.977 \\
\hline \multirow{2}{*}{ Aswan } & \multirow{2}{*}{259} & \multirow{2}{*}{251} & SSE: $-2(-1 \%)$ & SSE: $10(4 \%)$ & SSE: 10 & SSE: 0.985 \\
\hline & & & $\mathrm{HC} 1:-10(-4 \%)$ & $\mathrm{HC} 1: 14(5 \%)$ & HC1: 10 & HC1: 0.982 \\
\hline All mixed & 231 & 2444 & SSE: -2 (-1 \%)) & SSE: $18(8 \%)$ & SSE: 18 & SSE: 0.970 \\
\hline All mixed & 231 & 2444 & $\mathrm{HC} 1:-4(-2 \%)$ & $\mathrm{HC} 1: 16(7 \%)$ & HC1: 16 & HC1: 0.977 \\
\hline
\end{tabular}

Table 4. 


\begin{tabular}{|c|c|c|c|c|c|c|}
\hline Month & $\begin{array}{l}\text { Ground } \\
\left(\mathrm{W} \mathrm{m}^{-2}\right) \\
\end{array}$ & $\begin{array}{c}\mathrm{Nb} \\
\text { samples }\end{array}$ & $\operatorname{Bias}\left(\mathrm{W} \mathrm{m}^{-2}\right)$ & $\operatorname{RMSD}\left(\mathrm{W} \mathrm{m}^{-2}\right)$ & $\mathrm{SD}\left(\mathrm{W} \mathrm{m}^{-2}\right)$ & Correl \\
\hline \multirow{2}{*}{ Jan. } & \multirow{2}{*}{212} & \multirow{2}{*}{142} & SSE: $-4(-3 \%)$ & SSE: $15(10 \%)$ & SSE: 14 & SSE: 0.895 \\
\hline & & & HC1: $-4(-3 \%)$ & HC1: $12(8 \%)$ & HC1: 11 & HC1: 0.939 \\
\hline \multirow{2}{*}{ Feb. } & \multirow{2}{*}{211} & \multirow{2}{*}{179} & SSE: $-4(-2 \%)$ & SSE: $15(9 \%)$ & SSE: 15 & SSE: 0.907 \\
\hline & & & HC1: $-6(-3 \%)$ & HC1: 15 (9\%) & HC1: 14 & $\mathrm{HC} 1: 0.923$ \\
\hline \multirow{2}{*}{ Mar. } & \multirow{2}{*}{209} & \multirow{2}{*}{228} & SSE: $-5(-2 \%)$ & SSE: $18(8 \%)$ & SSE: 18 & SSE: 0.837 \\
\hline & & & HC1: $-8(-3 \%)$ & HC1: $18(8 \%)$ & HC1: 16 & $\mathrm{HC} 1: 0.865$ \\
\hline \multirow{2}{*}{ Apr. } & \multirow{2}{*}{211} & \multirow{2}{*}{271} & SSE: $-3(-1 \%)$ & SSE: $19(7 \%)$ & SSE: 19 & SSE: 0.730 \\
\hline & & & HC1: $-8(-3 \%)$ & HC1: $17(6 \%)$ & HC1: 16 & $\mathrm{HC} 1: 0.825$ \\
\hline \multirow{2}{*}{ May } & \multirow{2}{*}{211} & \multirow{2}{*}{298} & SSE: $-0.3(-0.1 \%)$ & SSE: $18(6 \%)$ & SSE: 18 & SSE: 0.634 \\
\hline & & & HC1: $-0.4(-.1 \%)$ & HC1: $15(5 \%)$ & HC1: 15 & $\mathrm{HC} 1: 0.722$ \\
\hline \multirow{2}{*}{ Jun. } & \multirow{2}{*}{211} & \multirow{2}{*}{319} & SSE: $5(2 \%)$ & SSE: $21(6 \%)$ & SSE: 20 & SSE: 0.429 \\
\hline & & & $\mathrm{HC} 1: 3(1 \%)$ & $\mathrm{HC} 1: 16(5 \%)$ & HC1: 15 & $\mathrm{HC} 1: 0.518$ \\
\hline \multirow{2}{*}{ Jul. } & \multirow{2}{*}{198} & \multirow{2}{*}{314} & SSE: $4(1 \%)$ & SSE: $17(6 \%)$ & SSE: 17 & SSE: 0.396 \\
\hline & & & HC1: $-1(-0.2 \%)$ & $\mathrm{HC} 1: 16(5 \%)$ & HC1: 16 & $\mathrm{HC} 1: 0.544$ \\
\hline \multirow{2}{*}{ Aug. } & \multirow{2}{*}{209} & \multirow{2}{*}{289} & SSE: $3(1 \%)$ & SSE: $19(7 \%)$ & SSE: 19 & SSE: 0.406 \\
\hline & & & HC1: $-4(-1 \%)$ & HC1: $17(6 \%)$ & HC1: 17 & HC1: 0.481 \\
\hline \multirow{2}{*}{ Sep. } & \multirow{2}{*}{209} & \multirow{2}{*}{251} & SSE: $-0.2(-0.1 \%)$ & SSE: $18(7 \%)$ & SSE: 18 & SSE: 0.669 \\
\hline & & & HC1: $-4(-2 \%)$ & $\mathrm{HC} 1: 16(6 \%)$ & HC1: 15 & $\mathrm{HC} 1: 0.664$ \\
\hline \multirow{2}{*}{ Oct. } & \multirow{2}{*}{208} & \multirow{2}{*}{200} & SSE: $-5(-3 \%)$ & SSE: $23(11 \%)$ & SSE: 22 & SSE: 0.688 \\
\hline & & & HC1: $-7(-5 \%)$ & HC1: $21(11 \%)$ & HC1: 20 & HC1: 0.701 \\
\hline \multirow{2}{*}{ Nov. } & \multirow{2}{*}{207} & \multirow{2}{*}{155} & SSE: $-6(-4 \%)$ & SSE: $16(10 \%)$ & SSE: 15 & SSE: 0.876 \\
\hline & & & HC1: $-7(-6 \%)$ & HC1: 13 (8\%) & HC1: 11 & $\mathrm{HC} 1: 0.932$ \\
\hline Der & 208 & 121 & SSE: $-5(-4 \%)$ & SSE: $17(13 \%)$ & SSE: 16 & SSE: 0.849 \\
\hline Dec. & 208 & 131 & HC1: $-6(-5 \%)$ & HC1: $12(9 \%)$ & HC1: 11 & $\mathrm{HC} 1: 0.932$ \\
\hline
\end{tabular}

Table 5

\begin{tabular}{|c|c|c|c|c|c|c|}
\hline Condition $\left(\mathrm{W} \mathrm{m}^{-2}\right)$ & $\begin{array}{c}\text { SSI } \\
\left(\mathrm{W} \mathrm{m}^{-2}\right)\end{array}$ & $\begin{array}{c}\mathrm{Nb} \\
\text { samples }\end{array}$ & $\operatorname{Bias}\left(\mathrm{W} \mathrm{m}^{-2}\right)$ & $\operatorname{RMSD}\left(\mathrm{W} \mathrm{m}^{-2}\right)$ & $\begin{array}{c}\mathrm{SD} \\
\left(\mathrm{W} \mathrm{m}^{-2}\right)\end{array}$ & Correl \\
\hline Low $(\mathrm{SSI}<100)$ & 42 & 92 & $\begin{array}{l}\text { SSE: } 3(3 \%) \\
\text { HC1: } 1(2 \%)\end{array}$ & $\begin{array}{l}\text { SSE: } 7(8 \%) \\
\text { HC1: } 7(8 \%)\end{array}$ & $\begin{array}{l}\text { SSE: } 7 \\
\mathrm{HC} 1: 7\end{array}$ & $\begin{array}{l}\text { SSE: } 0.604 \\
\text { HC1: } 0.657\end{array}$ \\
\hline $\begin{array}{l}\text { Medium } \\
(100<\mathrm{SSI}<200)\end{array}$ & 866 & 153 & $\begin{array}{l}\text { SSE: }-4(-2 \%) \\
\text { HC1: }-5(-3 \%)\end{array}$ & $\begin{array}{l}\text { SSE: } 16(10 \%) \\
\text { HC1: } 13(8 \%)\end{array}$ & $\begin{array}{l}\text { SSE: } 15 \\
\text { HC1: } 12\end{array}$ & $\begin{array}{l}\text { SSE: } 0.858 \\
\text { HC1: } 0.910\end{array}$ \\
\hline High $($ SSI>200) & 1596 & 277 & $\begin{array}{l}\text { SSE: }-1(0.3 \%) \\
\text { HC1: }-4(-2 \%)\end{array}$ & $\begin{array}{l}\text { SSE: } 19(7 \%) \\
\text { HC1: } 17(6 \%)\end{array}$ & $\begin{array}{l}\text { SSE: } 19 \\
\text { HC1: } 17\end{array}$ & $\begin{array}{l}\text { SSE: } 0.892 \\
\text { HC1: } 0.916\end{array}$ \\
\hline
\end{tabular}

Table 6 


\begin{tabular}{lccc}
\hline \multicolumn{1}{c}{ Station } & Record & $\begin{array}{c}\text { Range of dimming } \\
\left(\mathrm{W} \mathrm{m}^{-2}\right)\end{array}$ & $\begin{array}{c}\text { Rate of change } \\
\left(\mathrm{W} \mathrm{m}^{-2} \text { year }^{-1}\right)\end{array}$ \\
\hline Tamanrasset & $1995-2005$ & -7.9 & -0.7 \\
Bahtim & $1969-2005$ & 54.7 & 1.5 \\
Cairo & $1969-2005$ & 43.5 & 1.2 \\
Sidi Barrani & $1984-2005$ & -2.2 & -0.1 \\
Mersa Matruh & $1981-2005$ & 13.9 & 0.6 \\
Tahrir & $1969-1996$ & 21.7 & 0.8 \\
El Arish & $1986-2005$ & 16.8 & 0.8 \\
Sidi Bou Said & $1985-2000$ & 8.2 & 0.5 \\
Asyut & $1981-2005$ & 27.4 & 1.1 \\
El Kharga & $1971-2005$ & 17.3 & 0.5 \\
Aswan & $1980-2005$ & 25.2 & 1.0 \\
\hline
\end{tabular}

Table 7. 


\begin{tabular}{|c|c|c|c|c|}
\hline Station & 1970s & $1980 \mathrm{~s}$ & $1990 \mathrm{~s}$ & $2000 \mathrm{~s}$ \\
\hline \multicolumn{5}{|l|}{ Tamanrasset } \\
\hline Rate/year $\left(\mathrm{W} \mathrm{m}^{-2}\right.$ year $\left.^{-1}\right)$ & & & 5.4 (5 years) & -1.2 \\
\hline Decline $\left(\mathrm{W} \mathrm{m}^{-2}\right)$ & & & 21.8 & -6.1 \\
\hline \multicolumn{5}{|l|}{ Bahtim } \\
\hline Rate/year $\left(\mathrm{W} \mathrm{m}^{-2}\right.$ year $\left.^{-1}\right)$ & -2.0 & -1.3 & -1.5 & -2.3 \\
\hline Decline $\left(\mathrm{W} \mathrm{m}^{-2}\right)$ & -20.0 & -11.9 & -13.1 & -11.7 \\
\hline \multicolumn{5}{|l|}{ Cairo } \\
\hline Rate/year $\left(\mathrm{W} \mathrm{m}^{-2}\right.$ year $\left.^{-1}\right)$ & -2.0 & -1.8 & 2.6 & -1.1 \\
\hline Decline $\left(\mathrm{W} \mathrm{m}^{-2}\right)$ & -20.4 & -16.3 & 23.0 & -5.7 \\
\hline \multicolumn{5}{|l|}{ Sidi Barrani } \\
\hline Rate/year $\left(\mathrm{W} \mathrm{m}^{-2}\right.$ year $\left.^{-1}\right)$ & & 5.3 (6 years) & -0.9 & -6.4 \\
\hline Decline $\left(\mathrm{W} \mathrm{m}^{-2}\right)$ & & 26.3 & -7.9 & -31.9 \\
\hline \multicolumn{5}{|l|}{ Mersa Matruh } \\
\hline Rate/year $\left(\mathrm{W} \mathrm{m}^{-2}\right.$ year $\left.^{-1}\right)$ & & -1.0 (9 years) & 0.0 & -0.2 \\
\hline Decline $\left(\mathrm{W} \mathrm{m}^{-2}\right)$ & & -8.1 & -0.4 & -1.1 \\
\hline \multicolumn{5}{|l|}{ Tahrir } \\
\hline Rate/year $\left(\mathrm{W} \mathrm{m}^{-2}\right.$ year $\left.^{-1}\right)$ & -0.6 & -2.1 & 2.0 (7 years) & \\
\hline Decline $\left(\mathrm{W} \mathrm{m}^{-2}\right)$ & -5.6 & -18.9 & 12.2 & \\
\hline \multicolumn{5}{|l|}{ El Arish } \\
\hline Rate/year $\left(\mathrm{W} \mathrm{m}^{-2}\right.$ year $\left.^{-1}\right)$ & & $-2.4(4$ years $)$ & 0.6 & -2.6 \\
\hline Decline $\left(\mathrm{W} \mathrm{m}^{-2}\right)$ & & -7.1 & 5.4 & -12.9 \\
\hline \multicolumn{5}{|l|}{ Sidi Bou Said } \\
\hline Rate/year $\left(\mathrm{W} \mathrm{m}^{-2}\right.$ year $\left.^{-1}\right)$ & & -0.8 (5 years) & -0.2 & \\
\hline Decline $\left(\mathrm{W} \mathrm{m}^{-2}\right)$ & & -3.0 & -1.7 & \\
\hline \multicolumn{5}{|l|}{ Asyut } \\
\hline Rate/year $\left(\mathrm{W} \mathrm{m}^{-2}\right.$ year $\left.^{-1}\right)$ & & $-2.3(9$ years $)$ & 1.0 & -4.1 \\
\hline Decline $\left(\mathrm{W} \mathrm{m}^{-2}\right)$ & & -18.8 & 9.0 & -20.4 \\
\hline \multicolumn{5}{|l|}{ El Kharga } \\
\hline Rate/year ( $\left(\mathrm{W} \mathrm{m}^{-2}\right.$ year $\left.^{-1}\right)$ & 4.0 (7years) & $-2.2(9$ years $)$ & -1.6 & -0.8 \\
\hline Decline $\left(\mathrm{W} \mathrm{m}^{-2}\right)$ & 31.7 & -17.9 & -14.4 & -4.2 \\
\hline \multicolumn{5}{|l|}{ Aswan } \\
\hline Rate/year $\left(\mathrm{W} \mathrm{m}^{-2}\right.$ year $\left.^{-1}\right)$ & & -1.8 & 0.6 & -1.3 \\
\hline Decline $\left(\mathrm{W} \mathrm{m}^{-2}\right)$ & & -16.3 & 5.5 & -6.7 \\
\hline \multicolumn{5}{|l|}{ Mean } \\
\hline Rate/year (W m ${ }^{-2}$ vear $\left.^{-1}\right)$ & -0.2 & -1.8 & 0.7 & -1.2 \\
\hline Decline $\left(\mathrm{W} \mathrm{m}^{-2}\right)$ & -2.4 & -15.8 & 6.7 & -6.2 \\
\hline
\end{tabular}

Note: italic marked values means ascending of solar radiation.

Table 8. 


\section{FIGURE CAPTIONS}

Fig. 1. Monthly mean of SSI at Sidi Barrani measured at ground level (full line and diamonds) and from HC1 (stars) for years 1990s.

Fig. 2. As Fig.1, but for SSE.

Fig. 3 Monthly variation for RMSD and SD to both database HC1 and SSE by using all mixed data used.

Fig. 4. Annual mean of SSI for eight Egyptian sites (1969-2005).

Fig. 5. As Fig. 3 but for normalized annual mean of SSI.

Fig. 6. Map of the range of dimming in $\mathrm{W} \mathrm{m}^{-2}$. Black means range less than $-5 \mathrm{~W} \mathrm{~m}^{-2}$; dark grey, range from -5 to $0 \mathrm{~W} \mathrm{~m}^{-2}$ and so on every $5 \mathrm{~W} \mathrm{~m}^{-2}$. 


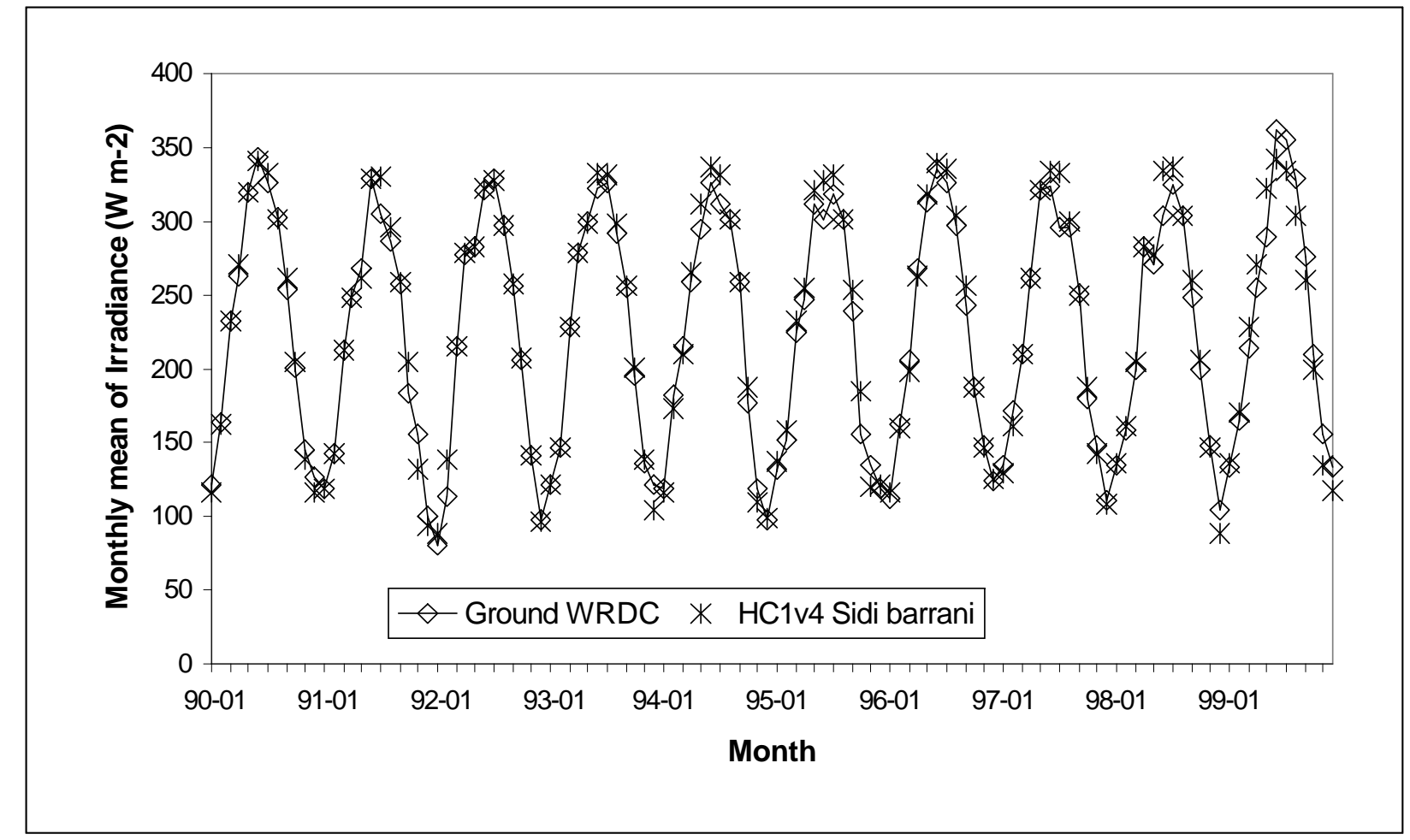

Fig. 1.

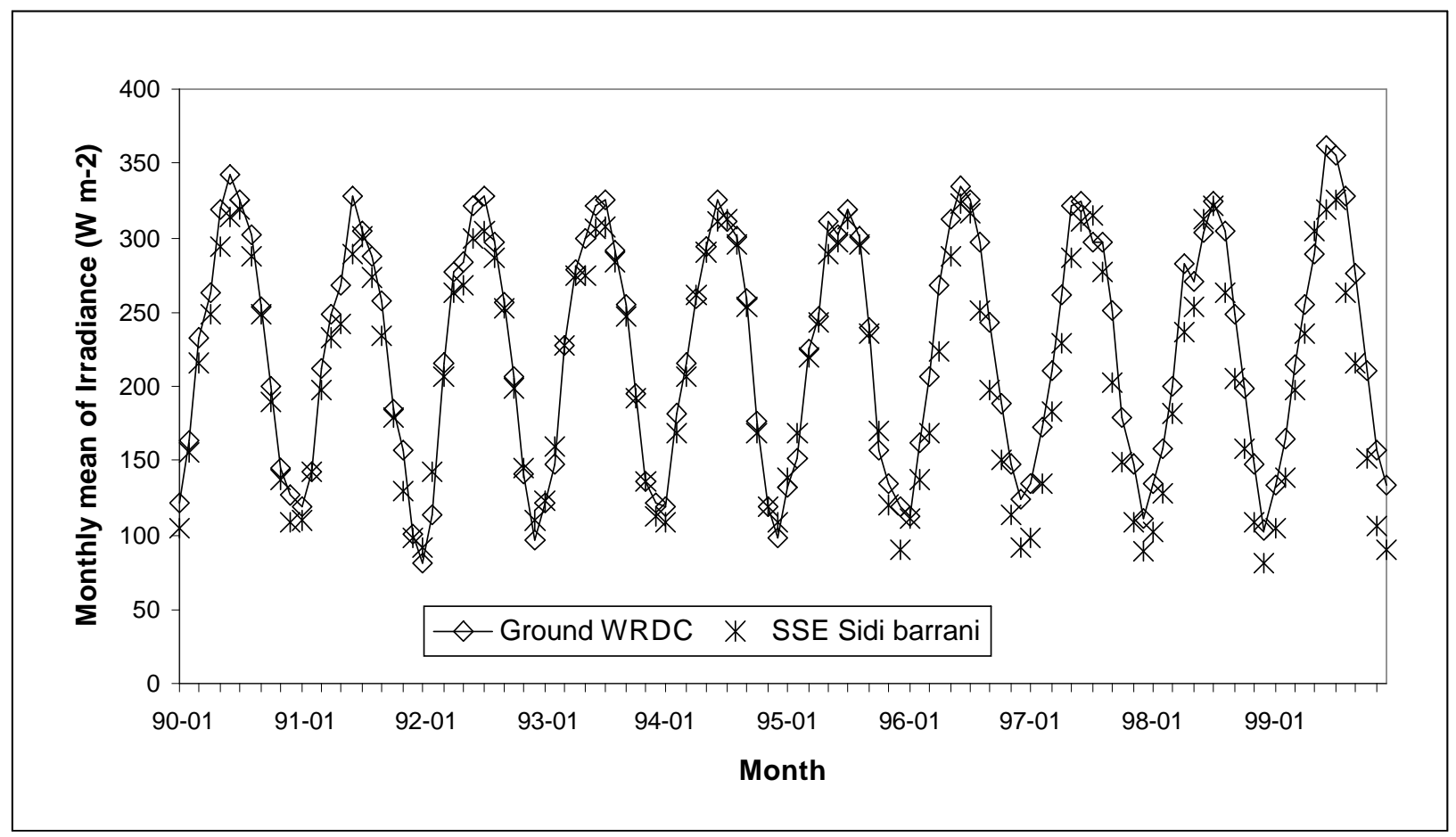

Fig. 2. 


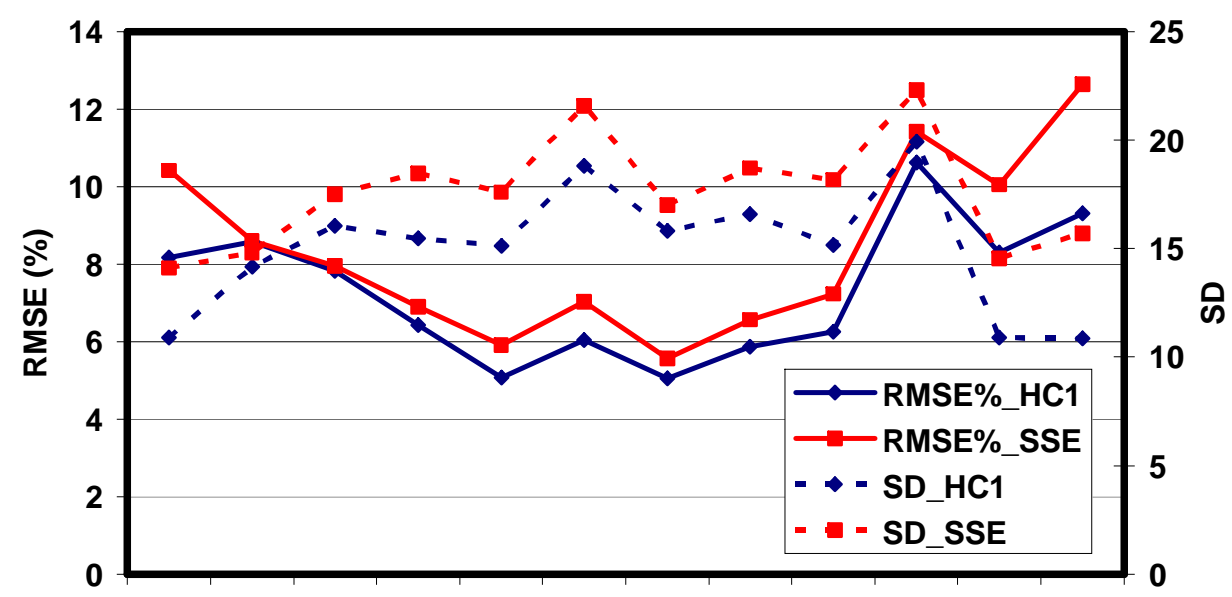

Jan. Feb. Mar. Apr. May Jun. Jul. Aug. Sep. Oct. Nov. Dec.

Month

Fig. 3
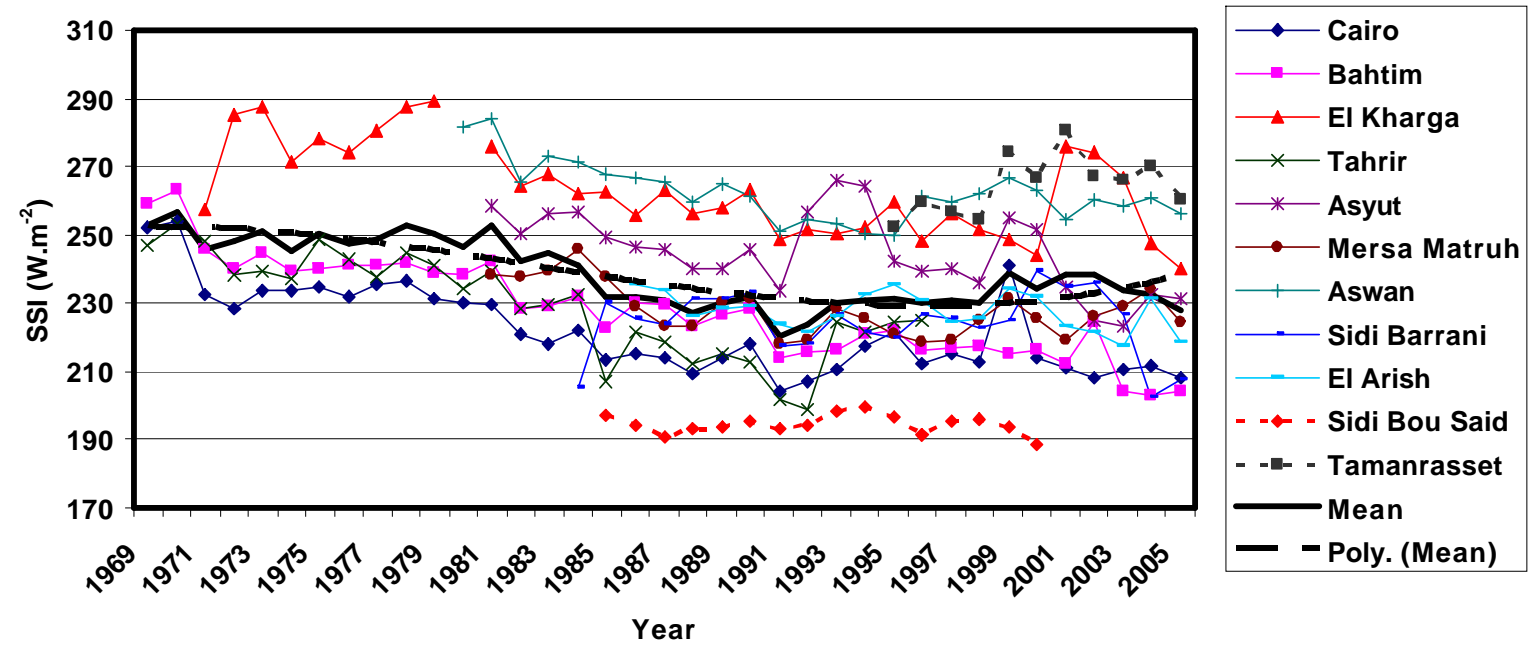

Fig. 4. 


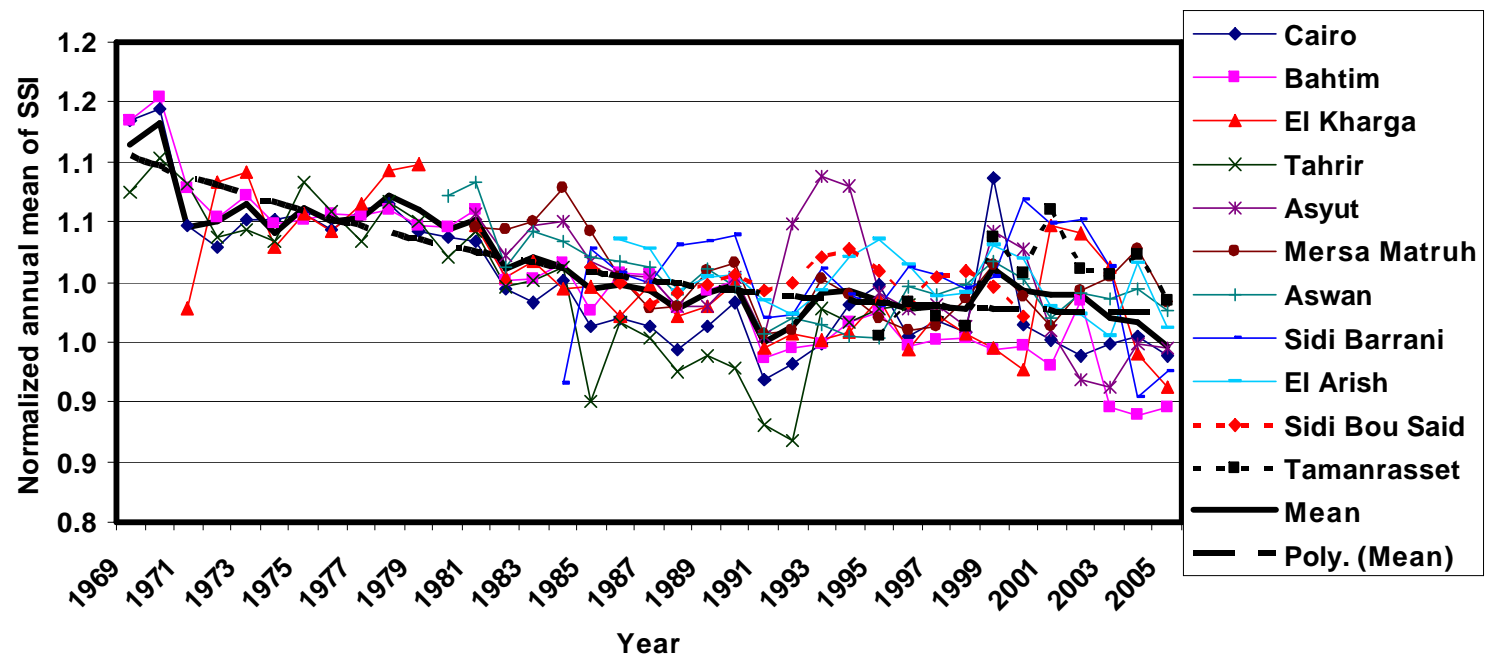

Fig. 5. 


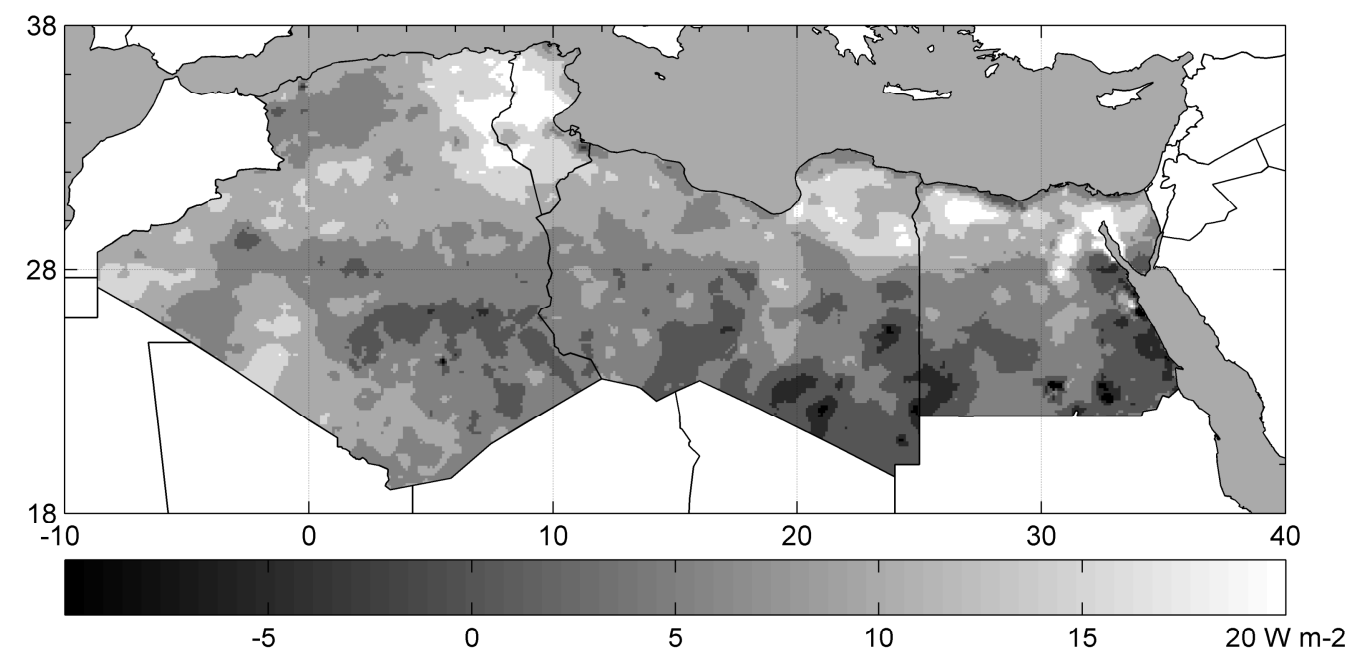

Fig. 6 